\title{
PENGUATAN KINERJA PEMASARAN MELALUI PROMOSI ONLINE PRODUK KELOMPOK UMKM TONGTENGPAKCUR TASIKMALAYA, JAWA BARAT
}

\author{
Adila Sosianika $^{1}$, Lusianus Kusdibyo ${ }^{2}$, Nono Wibisono ${ }^{3}$ \\ 1,2,3 Jurusan Administrasi Niaga, Politeknik Negeri Bandung \\ e-mail: ' ${ }^{2}$ adila.sosianika@polban.ac.id, ${ }^{2}$ kusdibyo@gmail.com, ${ }^{3}$ nn_wibisono@yahoo.com
}

\begin{abstract}
Abstrak
Kelompok UMKM Tongtengpakcur (Kelontong, Tengteng, Opak dan Cucur) di Tasikmalaya merupakan komunitas yang mewadahi para pengrajin makanan ringan khas Desa Cisayong, Kabupaten Tasikmalaya dengan berbagai varian produk yang dihasilkan. Kelompok UMKM Tongtengpakcur dengan jumlah anggota saat ini hampir mencapai 20 UMKM adalah tempat bagi para pengrajin binaan Desa Cisayong untuk saling belajar, tukar pikiran, membagi informasi maupun peluang usaha dalam hal pengembangan produk serta kiat-kiat peningkatan kinerja bisnis. Dari segi pemasaran dan penjualan produk, Tongtengpakcur masih sangat terbatas dan belum mampu berkembang seperti yang diharapkan. Kurangnya pemahaman pemilik akan strategi pemasaran mengakibatkan pemasaran produk terbatas hanya di sekitar daerah Cisayong dan Kota Tasikmalaya. Penjualan produk umumnya hanya mengandalkan pemesanan dari instansi setempat atau dengan cara menitipkan produk-produknya ke beberapa toko di kota Tasikmalaya. Tersedianya website dan media sosial Kelompok UMKM Tongtengpakcur diharapkan dapat menjadi solusi bagi mitra karena website dapat menjadi media promosi, komunikasi bahkan mungkin sekaligus transaksi. Melalui website dan media sosial Kelompok UMKM Tongtengpakcur diharapkan produk-produk UMKM binaanya dapat lebih dikenal, semakin banyak juga konsumen yang tertarik membeli produk karena jangkauan pasar lebih luas dan akhirnya berdampak positif pada peningkatan penjualan.
\end{abstract}

Kata kunci: kinerja pemasaran, umkm, website, promosi media sosial

\section{PENDAHULUAN}

Usaha Mikro, Kecil, dan Menengah atau UMKM di Indonesia memiliki peran penting dalam menopang perekonomian dan penyerapan tenaga kerja. Data tahun 2016 meperlihatkan bahwa perkembangan jumlah unit UMKM cukup positif dan signifikan yaitu kenaikan jumlah unit usaha baru sekitar $2,42 \%$ setiap tahunnya ${ }^{1}$. Jumlah keseluruhan UMKM di Indonesia mencapai 56,2 juta unit yang mampu menyerap $97,2 \%$ tenaga kerja dari total angkatan kerja yang $\operatorname{ada}^{2}$. Hal ini menunjukkan bahwa UMKM sangat berperan dalam penyerapan tenaga kerja dan berkontribusi pada pertumbuhan ekonomi dengan demikian UMKM juga berperan dalam mengurangi angka pengangguran dan kemiskinan.

Potensi pasar produk-produk UMKM di Indonesia sangat besar dan sangat menarik bagi pelaku UMKM. Hal ini menjadi suatu tantangan tersendiri bagi UMKM mengingat daya saing produk yang masih harus terus ditingkatkan untuk lebih kreatif dan inovatif agar dapat lebih kompetitif dalam 
memperebutkan pasar. Ternyata produk UMKM lokal masih belum mampu bersaing dengan UMKM negara lain seperti Korea Selatan, Jepang, Singapura, dan Hongkong ${ }^{3}$. Kondisi ini juga menunjukkan bahwa permasalahan utama yang dihadapi UMKM di Indonesia adalah faktor pengetahuan bisnis dan pemasaran ${ }^{4}$.

Kelompok UMKM Tongtengpakcur (Kelontong, Tengteng, Opak dan Cucur) di Tasikmalaya merupakan komunitas yang mewadahi para pengrajin makanan ringan khas Desa Cisayong, Kabupaten Tasikmalaya. Kelompok UMKM Tongtengpakcur adalah tempat bagi para pengrajin binaan untuk saling belajar, tukar pikiran, membagi informasi maupun peluang usaha dalam hal pengembangan produk serta kiat-kiat peningkatan kinerja bisnis. Sampai saat ini jumlah anggota binaan Kelompok UMKM Tongtengpakcur mencapai 20 UMKM masih belum memiliki media promosi (Tabel 1.). Keberadaan 20 UMKM ini di dukung dengan legalitas lengkap dari instansi terkait mulai dari TDP, SIUP, IG, Sertifikat halal, PIRT, kandungan nutrisi produk dan hal lain diperlukan dalam usaha.

\section{Tabel 1. Daftar UMKM Tongtengpakcur,} Tasikmalaya

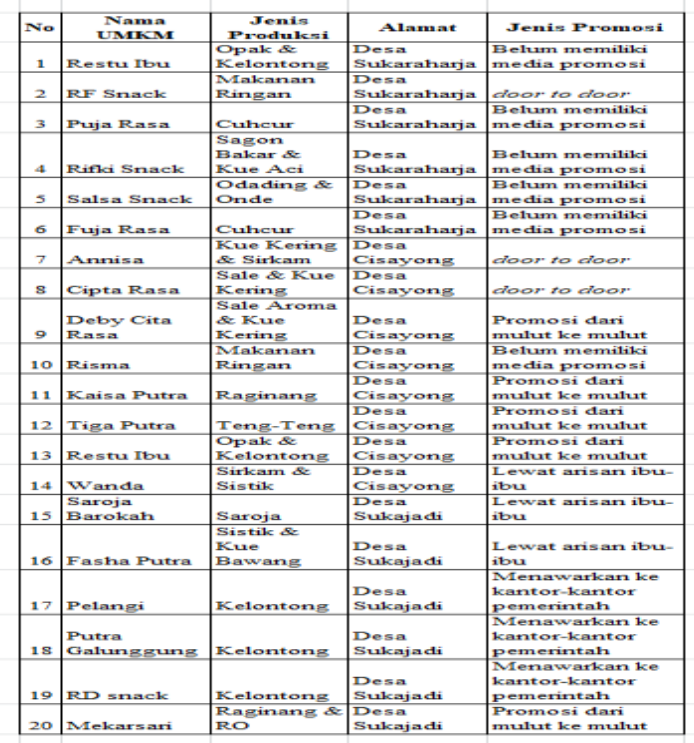

Beberapa produk UMKM binaan Tongtengpakcur sudah mengalami kemajuan baik dari segi kualitas produk maupun legalitas. Akan tetapi, dikarenakan umur, pengetahuan serta pengalaman anggota UMKM yang berbeda-beda, maka masih terdapat produk UMKM binaan yang memerlukan pengembangan. Banyak hal yang harus terus dilakukan dan dikembangkan oleh UMKM anggota binaan Kelompok UMKM Tongtengpakcur, terutama dalam memenuhi keinginan pasar oleh-oleh khas Tasikmalaya, Jawa Barat yang semakin hari semakin ketat persaingannya. Dari segi pemasaran dan penjualan produk, Tongtengpakcur masih sangat terbatas dan belum mampu berkembang seperti yang diharapkan. Selain itu juga dihadapkan pada persaingan pasar yang ketat dengan tumbuhnya jajanan-jajanan yang lebih modern seperti yang tersedia di berbagai minimarket dan supermarket.

Kurangnya pemahaman pemilik akan strategi pemasaran mengakibatkan pemasaran produk terbatas hanya di sekitar daerah Cisayong dan Kota Tasikmalaya. Penjualan produk umumnya hanya mengandalkan pemesanan dari instansi setempat atau dengan cara menitipkan produk-produknya ke beberapa toko di kota Tasikmalaya. Ada kendala perputaran modal bagi UMKM saat produk masuk minimarket dengan sistem konsinyasi (biasanya tidak lebih dari 50 persen produk yang terjual). Sehingga beberapa UMKM memutuskan memasarkan produknya hanya di rumah. Akibatnya, tingkat penjualan menjadi rendah rendah. Salah satu penyebabnya juga adalah mereka (UMKM) tidak memiliki media promosi (Tabel 1), mengakibatkan produk-produknya tidak begitu dikenal oleh kebanyakan masyarakat.

Berdasarkah hasil wawancara dengan tiga mitra UMKM binaan Kelompok UMKM Tongtengpakcur bersedia untuk kerjasama dalam program pengabdian ini. Setelah identifikasi situasi permasalahan yang 
dihadapi oleh mitra, maka kami menawarkan prioritas pemecahan masalah pada bidang pemasaran guna meningkatkan kinerja pemasaran mitra. Situasi permasalahan, penyebab dan solusi bagi mitra dapat digambarkan seperti diagram berikut:

\section{Diagram 1. Permasalahan Mitra beserta Penyebab dan Solusi}

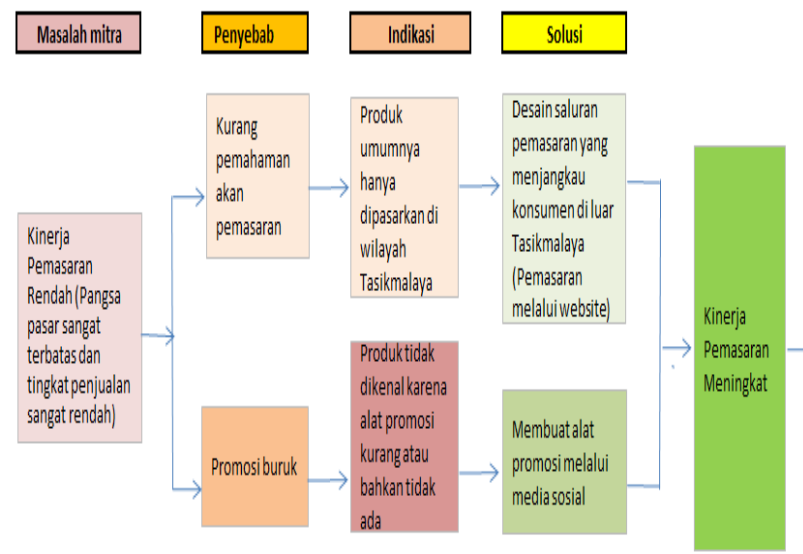

Solusi yang ditawarkan untuk meningkatkan kinerja pemasaran produkproduk binaan Kelompok UMKM Tongtengpakcur, solusi yang ditawarkan adalah tersedianya website dan media sosial komunitas Kelompok UMKM Tongtengpakcur yang bisa dioperasionalkan oleh pengelola. Website ini diharapkan dapat menjadi media komunikasi dan promosi mampu memperkuat daya tarik konsumen potensial untuk membeli produk-produk Kelompok UMKM Tongtengpakcur.

Pangsa pasar Kelompok UMKM Tongtengpakcur adalah pada umumnya instansi pemerintah serta konsumen golongan kelas ekonomi menengah kebawah. Sesuai karakter pola perilaku kelas sosial menengah kebawah bentuk promosi juga dinilai tepat adalah lewat media sosial yang sekaligus dapat menjadi wadah komunikasi dan promosi word-of-mouth.

\section{METODE}

Metode pelaksanaan dan evaluasi kegiatan desain website dam promosi media sosial dijelaskan dalam diagram 2 berikut ini:

Diagram 2. Mekanisme Kegiatan Peningkatan Saluran Pemasaran melalui Website dan Promosi melalui Media Sosial

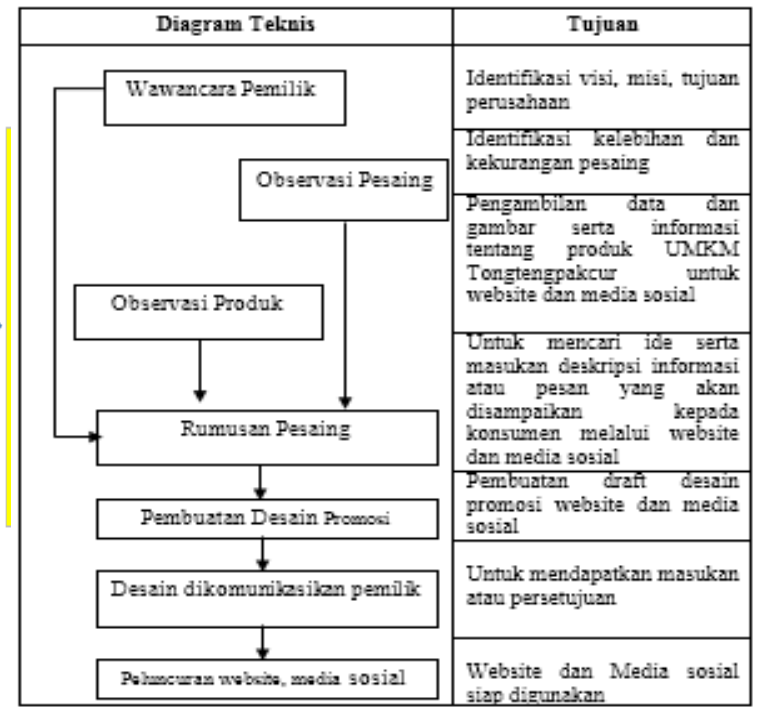

Diagram 2. menunjukkan kegiatan diawali dengan penentuan visi dan misi UMKM Tongtengpakcur yang sesuai produk serta fitur-fitur yang ditawarkan. Agar lebih tepat, maka penentuan visi dan misi akan dilakukan dengan cara mewawancarai pemilik ataupun pengelola UMKM serta observasi atau pengamatan langsung ke objek. Dari hasil wawancara dan observasi akan didapatkan jenis, keunggulan serta varian produk yang akan ditawarkan.

Untuk melengkapi informasi dan sebagai bahan masukan atau pertimbangan, perlu diketahui pula kegiatan-kegiatan promosi yang sudah dilakukan oleh para pesaing. Dengan berdasarkan pada hasil wawancara dan observasi serta analisa pesaing maka akan dibuat suatu rancangan atau desain website dan promosi media sosial alat promosi yang telah disepakati oleh pihak pemilik ataupun pengelola UMKM. 
Langkah-langkah ataupun metoda yang akan dilakukan guna mengevaluasi efektifitas kegiatan promosi dan penyuluhan kepada mitra adalah dengan cara mengetahui peningkatan produk-produk binaaan Kelompok UMKM Tongtengpakcur yang mampu dikenal, menarik perhatian bahkan menimbulkan minat beli banyak potensial konsumen. Kemudian yang tidak kalah pentingnya dalam jangka panjang perlu juga mengevaluasi dampak promosi website dan media sosial ini terhadap tingkat penjualan produk-produk binaaan Kelompok UMKM Tongtengpakcur.

\section{HASIL DAN PEMBAHASAN}

Merujuk pada permasalahan yang telah teridentifikasi, maka untuk meningkatkan kinerja pemasaran produk-produk binaan Kelompok UMKM Tongtengpakcur, pembuatan website untuk Kelompok UMKM Tongtengpakcur ini dilakukan melalui tahapan aktivitas sebagai berikut:

\section{Identifikasi visi, misi, tujuan Kelompok UMKM Tongtengpakcur}

Kegiatan diawali dengan penentuan visi dan misi Kelompok UMKM Tongtengpakcur yang membina UKM oleh-oleh khas Desa Cisayong Tasikmalaya yang sesuai dengan produk yang dimiliki. Agar lebih tepat, maka penentuan visi dan misi dilakukan dengan cara mewawancarai pengelola komunitas Gapura Sigar, serta observasi atau pengamatan langsung ke objek.

Dari hasil wawancara dan observasi dapat diketahui secara umum Kelompok UMKM Tongtengpakcur mempunyai visi dan misi yang serupa yaitu menjadi pengusaha/wirausaha yang mandiri dalam bidang kuliner khas Desa Cisayong Tasikmalaya yang berkualitas dan mampu diminati oleh konsumen, sehingga mampu menciptakan lapangan kerja bagi masyarakat sekitar dan meningkatkan perekonomian warga Tasikmalaya. Dari hasil wawancara dan observasi mengenai visi dan misi ini, maka akan menjadi masukan yang bermanfaat dalam mendesain website yang mampu mencerminkan visi dan misi semua anggota Kelompok UMKM Tongtengpakcur. Misalnya tema khas tentang kuliner maupun wisata khas Tasikmalaya akan menjadi tema yang ditampilkan dalam website.

\section{Identifikasi kelebihan dan kekurangan pesaing}

Selanjutnya setelah menggali visi dan misi setiap anggota Kelompok UMKM Tongtengpakcur, dilakukan identifikasi website pesaing yang sudah ada. Hal ini diperlukan guna melengkapi informasi dan sebagai bahan masukan atau pertimbangan dalam mendesain website.

Dari hasil pengamatan kami terhadap beberapa website UMKM kuliner khas daerah, maka dapat kami simpulkan untuk website toko online sudah tersedia dengan tampilan dan struktur website yang mudah digunakan. Selain itu kami juga menemukan beberapa website yang menampilkan kuliner disatukan dengan wisata bahkan hotel/resort khas daerah asal produk UMKM, sehingga tampak informasi tidak detail.

Namun dari hasil penelusuran secara online juga, kami belum menemukan website produk UMKM yang dikelola oleh komunitas atau paguyuban yang memang secara resmi dibentuk. Artinya, website yang sudah tersedia saat ini masih dikelola oleh pribadi, sehingga terkesan seperti blog pribadi. Hal ini menjadi suatu peluang untuk meluncurkan sebuah websiteKelompok UMKM Tongtengpakcur yang didirikan secara resmi.

\section{Pengambilan gambar untuk Website}

Dalam rangka menciptakan sebuah website yang berkualitas, maka kami melakukan pengambilan gambar produk hasil olahan Kelompok UMKM Tongtengpakcur yang layak untuk ditampilkan di website. 
4. Deskripsi informasi atau pesan yang akan disampaikan kepada konsumen

Dalam website paguyuban atau komunitas produk Kelompok UMKM Tongtengpakcur ini terdapat beberapa informasi yang ingin disampaikan yaitu:

- Profil Kelompok UMKM Tongtengpakcur beserta anggotanya

- Informasi tentang untuk menghubungi anggota Kelompok UMKM Tongtengpakcur

- Deskripsi produk-produk hasil olahan anggota Kelompok UMKM

Tongtengpakcur

- Galeri foto tampilan produk hasil olahan anggota Kelompok UMKM Tongtengpakcur

- Informasi kegiatan-kegiatan Kelompok UMKM Tongtengpakcur

- Sebagai tahap awal peluncuran website Kelompok UMKM Tongtengpakcur diharapkan informasi-informasi tersebut dapat menarik perhatian calon konsumen ataupun pengguna internet.

\section{Pembuatan draft Website}

Dengan berdasarkan pada hasil wawancara dan observasi serta analisa pesaing maka akan dibuat suatu rancangan atau desain website yang baik telah disepakati oleh pihak pemilik UKM ataupun pengelola Kelompok UMKM Tongtengpakcur . Adapun tahapan pembuatannya sebagai berikut:

1. Lakukan penginstallan xammp terlebih dahulu sebagai basis awal pembuatan sebuah website. Lalu klik xammp yang sudah terinstall di desktop untuk melakukan pengaturan serta pengaktifan dalam pembuatan website.

2. Setelah melakukan pengaturan, buka Mozilla Firefox untuk selanjutnya pembuatan database sebuah website. Dengan mengisi beberapa form sebagai basis website.
3. Setelah database dibuat, selanjutnya memasukkan form yang telah dibuat dalam XAMMP ke dalam Wordpress.

4. Lalu setelah masuk kedalam wordpress, langkah selanjutnya adalah melakukan konfigurasi terhadap beberapa fitur yang diperlukan dalam sebuah website.

5. Untuk menambahkan menu pada header website seperti gambar dibawah ini, caranya dengan menambahkan Pages.

6. Juga bisa menambahkan beberapa sub menu di dalam main menu, dengan cara menempatkan sub menu dibawah menu (sebagai sub item dari main menu).

7. Untuk mengisi konten pada menu bisa dengan melakukan pengisian form pada tools pages. Dengan memilih Add Pages lalu isi sesuai konten yang diinginkan.

8. Untuk menambahkan Post News seperti dibawah ini, lakukan dengan cara menambahkan Post.

9. Selanjutnya untuk memperindah tampilan website, pilih pengaktivasian themes pada website.

10. Apabila ingin menambahkan Widgets seperti Calendar ataupun yang lainnya dapat diaktifkan.

11. Pada akhirnya Website dengan tampilan lengkap sudah siap ditampilkan pada alamat umkmcisayong.com, seperti berikut ini:

\section{Halaman Beranda}

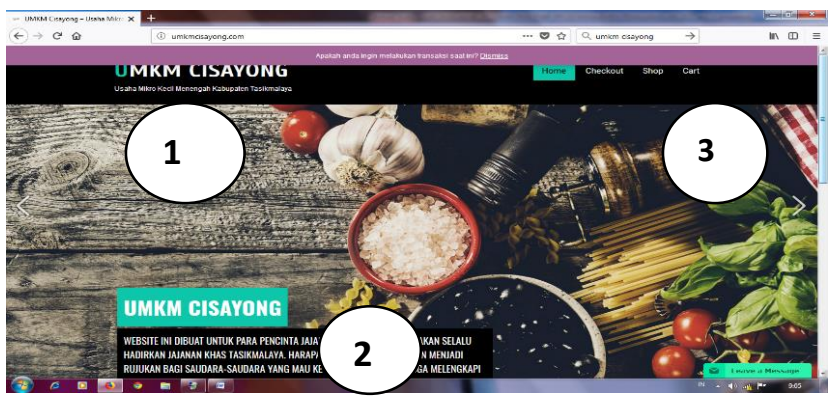

Deskripsi:

1) Tampilan halaman utama website merupakan tampilan yang pertama kali dilihat oleh pengunjung website. 
Pada website umkmcisayong.com ini tampilan halaman utamanya memuat foto geografis Kabupaten Tasikmalaya. Hal itu akan memberikan kesan pengunjung untuk lebih mengenal Kabupaten Tasikmalaya, khususnya Kecamatan Cisayong.

2) Nama website, yaitu umkm cisayong. Sebagai identitas perusahaan yang memproduksi produk.

3) Pada bagian kanan atas halaman utama terdapat beberapa fasilitas menu bagi pengunjung. Pertama menu Home, menu ini dilinkkan kepada halaman utama website yang terdapat gambar hidernya. Kedua menu my account, menu ini digunakan untuk mencatat database pengunjung atau calon pembeli. Ketiga menu Checkout, menu ini digunakan untuk pengunjung setelah mengnjungi website umkmcisayong.com. Keempat menu Shop, yaitu menu yang menampilkan produk dari pengrajin umkm cisayong meliputi harga, deskripsi produk dan informasi diskon. Kelima menu cart, yaitu menu untuk keranjang belanja untuk produk yang telah dipilih pengunjung

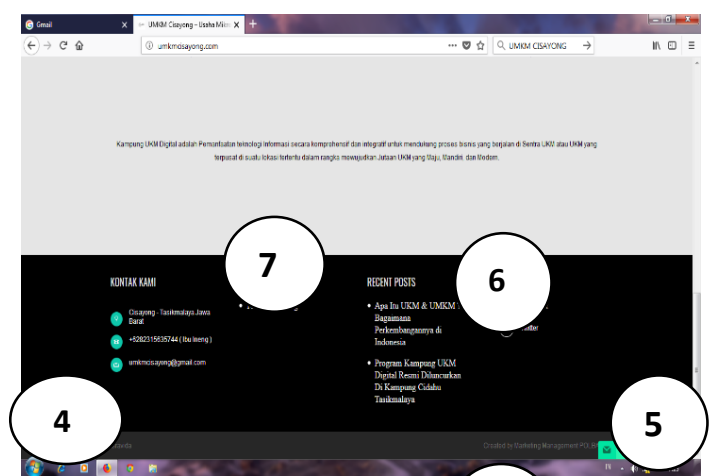

4) Informasi mengenai (8) ak dari pengusaha umkm cisayong. Pengunjung dapat menggunakan nomor kontak tersebut untuk kepentigan bisnis, seperti pesanan, konfirmasi, pengaduan keluhan dll.
5) Website umkmcissayong.com ini terintegrasi dengan media sosial dari umkm cisayong, seperti instagam, twitter dan facebook.

6) Pada halaman website ini terdapat artikel yang memuat informasi seputar perkembangan umkm, tidak hanya di Tasikmalaya akan tetapi di seluruh Indonesia.

7) Informasi jumlah traffic pengunjung (Visitors) di halaman depan website

8) Terdapat juga chat interaktif sebagai media komunikasi dengan pengujung website.

\section{Halaman Produk}
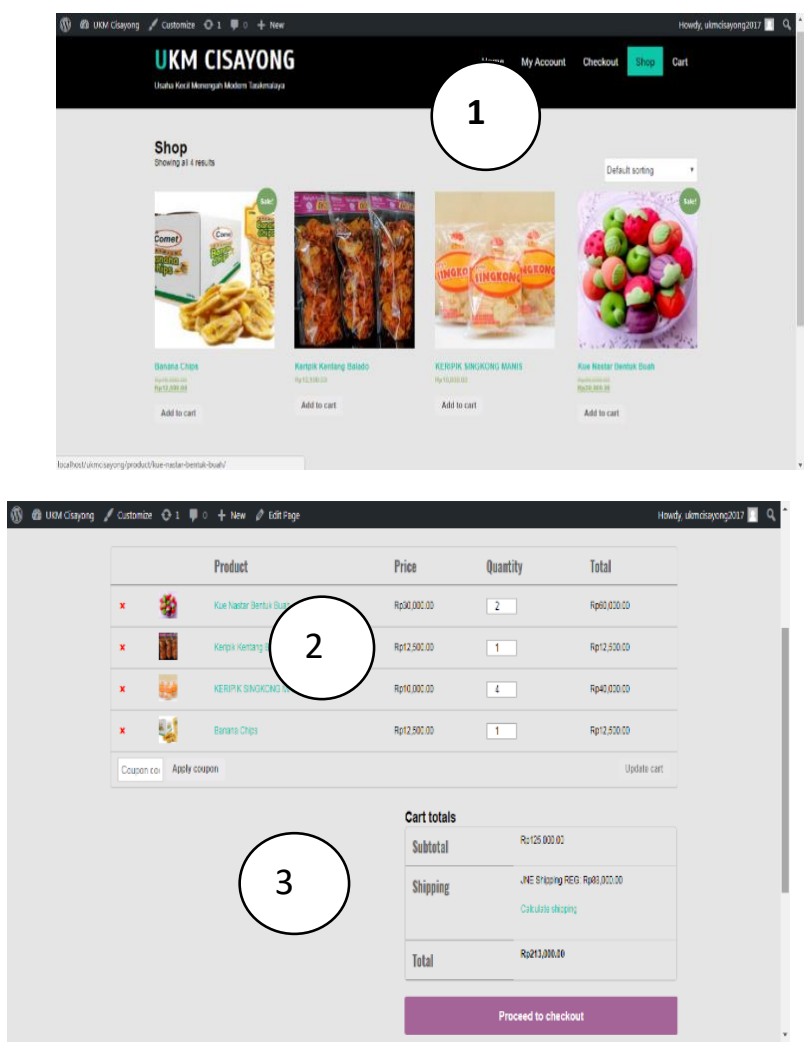

Deskripsi:

1) Pada halaman produk ini merupakan bagian dari menu shop yang memuat tampilan jenis produk yang dilengkapi dengan deskripsi produknya, seperti harga, komposisi, ketersediaan dan informasi diskon. 
2) Pada halaman ini, pengunjung diberikan informasi mengenai detail harga produk dan jumlah harga yang harus dibayar oleh pengunjung

3) Setelah produk tersebut dipilih dan ditetapkan harganya, maka selanjutnya akan dikirim ke pengunjung melalui halman shipping. Di halaman shipping ini pengunjung diminta mengisi alamat dimana produk itu harus diterima. Karena memakai jasa logistik akan dikenakan biaya kiriman.

Selanjutnya, pembuatan promosi media sosial untuk Kelompok UMKM Tongtengpakcur dilakukan melalui tahapan aktivitas sebagai berikut:

1. Pamflet akan dipasang atau diposting dimedia sosial, seperti instagram dan facebook. Pamflet merupakan sebuah tulisan yang berisi tentang suatu informasi yang terdiri dari tulisan termasuk gambar didalamnya yang umumnya dibuat pada selebaran dan tidak dijilid atau dibukukan.

2. Pamflet harus memiliki warna yang cerah, terlebih untuk produk makanan, hal itu untuk menstimulus konsumen.

3. Pamflet yang disajikan untuk diposting di media sosial memiliki tampilan yang simple, karena deskripsi akan dituangkan di caption akun kita. Kalaupun deskripsi produk akan dimasukan kedalam pamflet harus secara generik/umum agar pamflet tetap terlihat menarik.

4. Dalam mendesain pamflet dapat menggunakan alternatif aplikasi, diantaranya menggunakan aplikasi corel draw dan photoshop. Pada buku ini, pamflet yang dibuat menggunakan aplikasi photoshop.

5. Media sosial yang akan digunakan untuk promosi diantaranya adalah Instagram. Adapun manfaat promosi melalui Instagram adalah:

- Aplikasi mudah untuk dioperasikan
- Aplikasi banyak yang mengakses dari semua kalangan

- Promosi dapat dilaksanakan dengan berkala

- Kegiatan promosi lebih interaktif dengan konsumen, bisa melalui video dan gambar.

- Instagram menggunakan penargetan Ads yang menyerupai Facebook Ads, sehingga memungkinkan untuk memperoleh informasi pengguna Instagram yang sangat spesifik.

Berikut adalah tampilan promosi produk

UMKM Cisayong di media sosial Instagram:

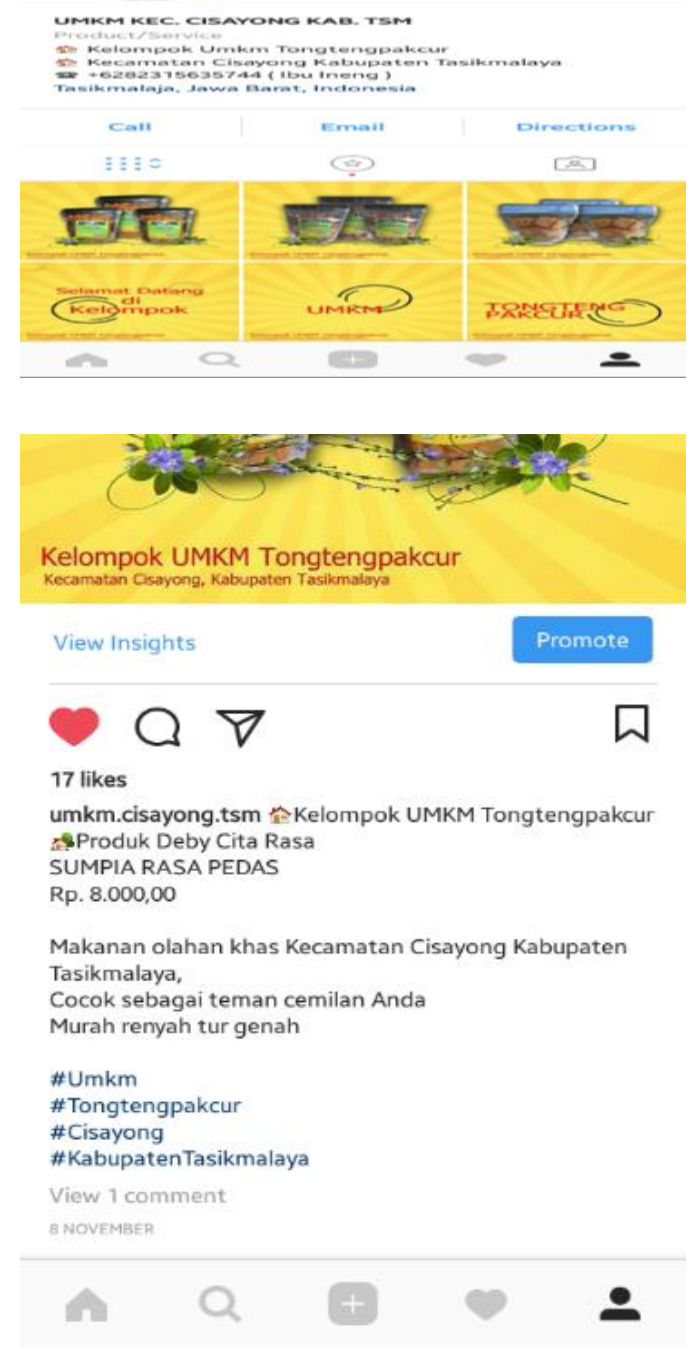




\section{SIMPULAN DAN SARAN}

Tersedianya website dan media sosial Kelompok UMKM Tongtengpakcur diharapkan dapat menjadi solusi bagi mitra karena website dapat menjadi media promosi, komunikasi bahkan mungkin sekaligus transaksi. Melalui website dan media sosial Kelompok UMKM Tongtengpakcur diharapkan produk-produk UMKM binaanya dapat lebih dikenal, semakin banyak juga konsumen yang tertarik membeli produk karena jangkauan pasar lebih luas dan akhirnya berdampak positif pada peningkatan penjualan.

Adapun target luaran dari program pengabdian kepada masyarakat ini yaitu tersedianya website serta promosi media sosial Kelompok UMKM Tongtengpakcur telah dihasilkan. Oleh karenanya, pengelolaan website dan media sosial menjadi penting guna meningkatkan kinerja pemasaran anggota Kelompok UMKM Tongtengpakcur. Misalnya saja dengan mengevaluasi secara berkala respon pengunjung website maupun media sosial Kelompok UMKM Tongtengpakcur serta penting juga selalu memberikan update informasi terkini tentang produk-produk Kelompok UMKM Tongtengpakcur. Untuk itu, disarankan kepada pengelola Kelompok UMKM Tongtengpakcur agar selalu memelihara website dan media sosial yang telah tersedia dengan menyediakan informasi terkini seputar produk maupun kegiatan Kelompok UMKM Tongtengpakcur.

Selanjutnya, guna meningkatkan citra atau image Kelompok UMKM Tongtengpakcur, maka alamat website maupun media sosial sebaiknya dicantumkan juga di setiap kemasan produk. Sebagai salah satu cara memonitor penggunaan website, kami juga telah menambahkan traffic pengunjung di halaman depan website (sampai tanggal 30 Desember 2017 tercatat 104 pengunjung) serta menambahkan chat interaktif sebagai media komunikasi dengan pengujung website.

\section{UCAPAN TERIMA KASIH}

Artikel ini merupakan hasil dari kegiatan Pengabdian Kepada Masyarakat yang dibiayai oleh DIPA Politeknik Negeri Bandung sesuai dengan Surat Perjanjian Pelaksanaan Kegiatan No:679-10/PL1.R7/PM/2017

\section{DAFTAR PUSTAKA}

[1] Badan Pusat Statistik.http://www.bps.go.id

[2]SWAonline, 2014. Tantangan dan Peluang UKM Jelang MEA 2015. http://swa.co.id/business-

research/tantangan-dan-peluang-ukmjelang-mea-2015. Diakses tanggal 12 Juni 2017.

[3] Primadhyta, Safyra 2015. Mendag Nilai UMKM Lokal Kurang Promosi dan Inovasi.

http://www.cnnindonesia.com/ekonomi/20 151105155137-92-89715/mendag-nilaiumkm-lokal-kurang-promosi-dan-inovasi/. Diakses tanggal 12 Juni 2017.

[4]Sanusi, 2015. Masalah UKM di Indonesia tidak melulu soal permodalan. http://www.tribunnews.com/bisnis/2015/08 /03/masalah-ukm-di-indonesia-tak-melulusoal-pemodalan. Diakses tanggal 12 Juni 2017.

[5] Kotler, Philip \& Amstrong, Gary. 2014. Principles of marketing. New Jersey: Prentice Hall Inc.

[6] Al Hafidz, Muhammad Perkasa, 2015. Masalah Utama UKM Indonesia? Ini Kata Ketua IMA. http://marketeers.com/article/masalahutama-ukm-indonesia-ini-kata-ketuaima.html. Diakses tanggal 12 Juni 2017. 
DIFUSI

Volume 1, No. 2, Juli 2018 